\title{
Examining Reading Comprehension through the use of Continuous Texts and Hypertexts.
}

Carla Viana Coscarelli

\begin{abstract}
In this paper we present the results of an experiment that aims to verify the influence of the presentation format - hypertext or continuous - in reading comprehension. A group of students, who are familiar with computers, read an advertisement in one of the formats: hypertext or continuous. After reading the text the students answered questions that aimed to verify some reading skills: global comprehension, retrieving information, making inferences and giving opinion. Both the text and the answers given by the students were analyzed using the Theory of Mental Spaces proposed by Fauconnier and Turner (2002). Although a quantitative analyses of the answers has pointed to an advantage of the hypertext format, qualitative analyses show that, regardless of the presentation format, the students could understand the advertisement, and were able to deal with different mental spaces in a very creative and efficient way.
\end{abstract}

Key words: reading, hypertexts, mental spaces.

\section{Resumen}

En este artículo se presentan los resultados de un experimento cuyo objetivo es el de verificar la influencia del formato de presentación ya sea este hipertexto o continuo en la comprensión lectora. Un grupo de estudiantes familiarizados con el uso del computador, leyeron un aviso publicitario en uno de los dos formatos: hipertexto o continuo. Una vez leído el aviso, los estudiantes respondieron una serie de preguntas tendientes a verificar habilidades lectoras tales como: comprensión global, identificación de información, inferencias y opiniones. Tanto el texto como las respuestas dadas por los estudiantes fueron analizadas usando la Teoría de los Espacios Mentales propuesta por Fauconnier and Turner (2002).A pesar de que el análisis cuantitativo de las respuestas indicaban una ventaja en el formato de hipertexto, el análisis cualitativo mostraba que independientemente del formato los estudiantes podían entender el aviso y podían manejar diferentes espacios mentales de una manera muy creativa y eficiente.

Palabras claves: lectura, hipertextos, espacios mentales.

* Received: 02-02-07/Accepted 09-10-07 


\section{Introduction}

We describe in this paper one of the experiments which is part of a research that aims to verify the influence of the presentation format - hypertext or continuous - in reading comprehension. Two versions of different texts were built: one in hypertext format and another in continuous format. What we call continuous is known as linear or printed texts, in which the information is presented in a sequence, as it is usually done in books and other printed texts. The hypertext version is composed by one main text from which many links are connected. These links lead to information about the text, and are presented as hyperlinks in the hypertext format, and as a linear text in the continuous format.

Some studies (Landow, 1992; Snyder, 1996; Xavier, 2004; Ramal, 2002) argue that reading hypertext is different from reading continuous texts, since the former is essentially different from the latter. In those studies, hypertext is usually taken as a non- linear text that has no primary axis of organization, no center. Besides that, they argue that hypertexts require a more active reader, who will be an independent and autonomous constructor of meaning. The reader will also be the writer, since he can add information to the text ${ }^{1}$.

Contrary to what has been largely said about hypertexts, our hypothesis here is that there is, actually, no strong enough reason to believe that there are substantial differences in reading comprehension generated by these two different formats of text presentation, as long as the navigation tools of the digital text are familiar to the reader.

Hypertext was seen as a mechanism that would make a revolution on the acts of writing and reading (Landow, 1992; Ramal, 2002), but there are, however, some studies that do not show this expected superiority of hypertexts in relation to linear texts (Rouet et al., 1996). Some researchers find those results difficult to explain, but they reinforce our belief that there is no such thing as linear reading, and that the physical differences among hypertexts and linear texts may not cause differences in text comprehension, since no text is linear and no reading is a linear process (Coscarelli, 2005).

One of the main differences between our beliefs and the ideas presented by researchers that argue for considering hypertext a revolution as far as writing and reading are concerned, such as Landow (1992) and others, is that they focus on navigation, on how the content is presented, and the user's

1 Our criticisms about this approach are discussed in detail in Coscarelli (2006). 
interaction with the text, while we focus our attention on text comprehension as a cognitive process. That is why they consider the lack of linearity one of the main features of hypertext while we argue that every text is a hypertext (since no text is linear), and every reading process is essentially hypertextual (because reading is not a linear process). Distinct approaches to the same subject - hypertext - lead to different results. This explains part of the discrepant conclusions that research on hypertext has to face.

In this paper we present one of the experiments made in order to verify the influence of the presentation format in reading comprehension. The text chosen for this experiment was an advertisement of Campari (Figure 1), published in a Brazilian national magazine.

$$
\text { (He provokes) (Only he is like this) }
$$

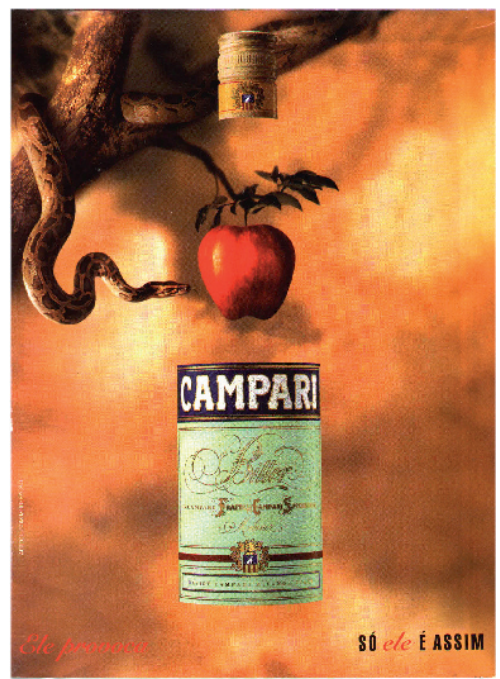

Figure 1: Campari ad

What called our attention to this advertisement was how it deals with information from different domains that together compose another new domain. In order to understand this text the reader needs, among other things, to activate his knowledge about Campari and about the act of drinking, and needs, on the other hand, to notice the reference made in the text to the story of the Original Sin told in the Bible, in which Adam and Eve are convinced by the serpent to eat the forbidden fruit - an apple. 
Based on the theory of mental spaces proposed by Fauconnier (1994, 1996, 1997) and Fauconnier $\mathcal{E}$ Turner (2002), we argue that, in order to understand this advertisement, the reader needs to activate at least two different mental spaces which, combined, generate a third one in which the other two blend. Fauconnier defines mental spaces as

"little numerous packets of working memory that we construct as we think and as we talk. We connect them and we also relate them to much more stable background knowledge and a lot of language. And grammar for that matter gives evidence of these hidden mental activities and connections to mental spaces." (Fauconnier - interview Coscarelli, 2005)

In the advertisement, one of the mental spaces (Figure 2) brings elements of the Bible - the apple, Adam and Eve and the serpent - which evoke the idea of temptation and sin. The other space is evoked by Campari and the consumers of this drink. A third space will be built by projections and correspondences that can be made between these spaces. The apple and the drink are blended in this third space as an element that has features of both of them, the same happening to the serpent and the consumer.

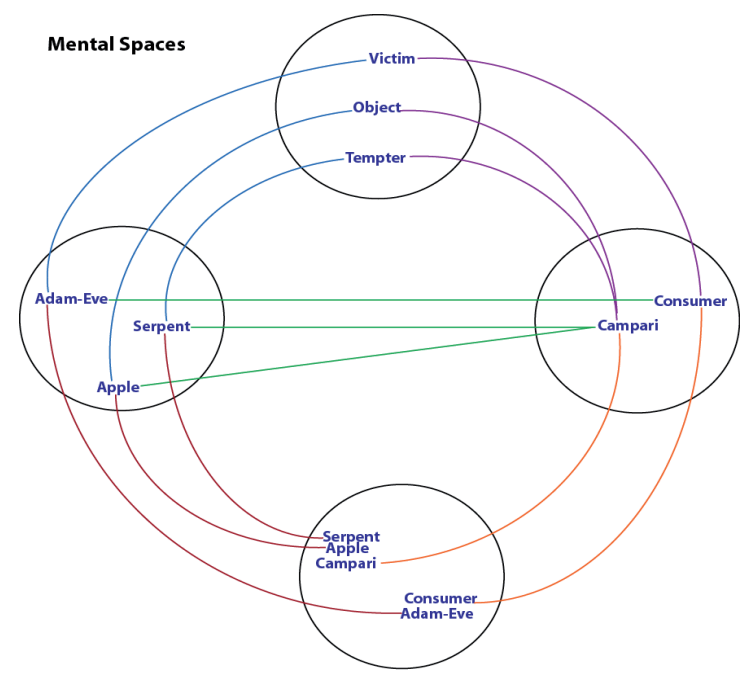

Figure 2: Mental Spaces evoked by the ad

There is also a generic space that brings structural and more general information about the idea of temptation. This space allows us to perceive more easily the 
relationship between the other two domains: the biblical domain (the original $\sin$ ) and the domain of the act of drinking. In the biblical space, we have the serpent and the apple, shown in the advertisement, and the characters Adam and Eve, who can be inferred, since they are very important elements in this context. Much more information may be inferred during the activation of this frame, one of which seeming to be the fact that the serpent convinced Adam and Eve that they should try the apple and, as a consequence of their action, they were expelled from Paradise. This frame can also activate our knowledge of the Christian tradition of using this myth as a form of controlling sexuality, in which sex is considered a sin and where sinners will be punished.

In the mental space of drinking, we have Campari and the consumer. In this space there are two elements, as opposed to the generic frame of temptation and the biblical space where there are three elements; here, the tempter and the object of desire are assembled in the same element, which is the drink. In this domain, the effects of drinking Campari, i.e. "fall into temptation" and "try the forbidden fruit" are very positive ones, as opposed to what happens in the biblical space. No one is expelled from Paradise; on the contrary, they are included in it and in all the universe of pleasure that results from this inclusion.

In comprehending this advertisement, these two domains are integrated in a third one in which features of the serpent, the apple and Campari are compressed in only one element. In this third space Adam, Eve and the consumer are also blended forming another element that compresses features of these two figures. In this blend, many inferences can be produced. Here Campari is at the same time serpent and apple, i.e. it is the tempter and the desired object, and the consumer is Adam and Eve, who will try the drink. Meaning is built out of this creation and integration of mental spaces.

In each of these spaces there is a cause-effect relation that needs to be detected by the reader. In the generic space the tempter tells the 'victim' not to resist the desired object and this relation is projected into the other spaces. In the biblical space, the serpent convinces Adam and Eve that they should try the apple (resulting in their being expelled from Paradise), and, in the drinking space, Campari dares the consumer to have this drink (resulting in his admission into paradise). Understood as metaphors, those spaces activate many other spaces and possible interpretations. 
Among the mental spaces created and articulated there are other relations that need to be detected, as the relations of identity, time and space. We can find analogies and dissimilarities among the elements that compose the mental spaces activated by this advertisement There is analogy and identity between the apple and Campari, as well as between the serpent and Campari, and there is a correlation between Adam and Eve and the consumer, i.e., there is a correspondence between these elements in the different spaces. On the other hand, the narrative and the characters of the biblical narrative need to be projected into the domain of drinking, which happens in a different time and space. It is not the time of the creation of the universe, but modern times in which the human being has already been created, expelled from Paradise, and has covered a long historical and evolutionary line. It is not the space of the Garden of Eden, but a bar, a restaurant, a house, an apartment, as we conceive them nowadays. The act of drinking Campari has the power to transform a modern place into paradise.

The blending, or the space that results from the integration of the other spaces, is composed by the compression of these elements. In this space there is no Adam and Eve, and no consumer, but there is one element that introduces features of both: a consumer that, for instance, wants to try the forbidden fruit, and knows that doing so does not mean risking being expelled from paradise. There is not an apple or Campari, but a Campari-apple that gathers features of both, being not only a drink, but a drink that, like the apple, provokes the consumer's desire for trying it. As opposed to the apple, this takes him/her to paradise. The idea of paradise is also different. It is not necessarily the place where everything is perfect and where there is no sin, but a place where "sinning" is good (and it is not a sin). It is worth noticing that there is always another projection that is metaphoric, and that (at least) duplicates the possible relations among these spaces, and the interpretations that they can yield. A literal interpretation of "sinning", for instance, would be eating the apple, but when considered metaphorically, could have a sexual connotation.

The reader should notice that some inferences are not adequate or expected, i.e., some interpretations should not be made "because they all violate either our conventional knowledge or the event structures associated with the target" (Reading Minds, p.7). Among them we can mention the fact that Adam and Eve were expelled from Paradise for trying the apple, and this can be considered a negative effect. Drinking Campari is a "sin", meaning 
that it is giving in to temptation, but it does not imply that this action will have a negative effect; on the contrary, sinning/drinking, in this case, takes the consumer to a better "place", to the "Garden of Eden", to "paradise". A wide range of inferential possibilities are opened, and new mental spaces can be built, among which the sexual connotation, reinforced by the red color used in the words.

Another interesting element on this text is the pronoun "he" in the expressions "he ${ }^{2}$ provokes" and "only he is like this". This pronoun reinforces the creation and integration of the spaces we have mentioned, being part of them. In these expressions, the anaphoric pronoun "he", besides referring to Campari in the drinking frame, also has correspondences in the biblical space, and is projected in the blended space. In the expression "only he is like this", the pronoun "he" seems to refer to Paradise or to the fruit in the biblical space, and to Campari in the drinking space. It is worth noticing that this pronoun seems to compress all the elements in the blended space - apple/snake/Campari and the Adam-Eve/consumer - driving us to the conclusion that those who drink Campari, the Adam-Eve/consumers, will be as attractive, as irresistible, as unique, and as powerful as the apple/snake/Campari. This seems to be an unusual case in which there is blending inside the blending space. Here the elements which compose the blended space are integrated to build another space where those elements - in this case apple/serpent/Campari and AdamEve/consumer - are integrated in a relationship of identity and uniqueness in one element that presents features of each one of them.

This is a very rich text as far as its interpretative possibilities are concerned, and this is one of the reasons why it was selected to be part of this research.

We expected, with this experiment, to verify whether the presentation format of this text influences reading comprehension. In order to do that, some reading abilities were focused: global comprehension of the text, information finding, inference production, and giving opinion.

The experiment, as well as some data and results will be briefly presented in the following sections.

2 This would be a difficult word game in English because the pronoun used to refer to Campari would be "it". In Portuguese, "ele" (he) is used either for humans and objects, enabling this polysemy. 


\section{Participants}

The participants of this experiment were fourteen Brazilian undergraduate students majoring in Communication Studies, in their first semester at university (Universidade Federal de Minas Gerais). They were on average 21 years old, very familiar with computers, and they participated in this experiment as part of the activities in Portuguese Class. They were asked to read the text in order to answer questions presented after the reading.

\section{Materials}

The main materials of this experiment were two versions of the advertisement: the hypertextual and the continuous ones, both written in Portuguese. In order to build the hypertextual version of the ad, links were inserted (Appendix 1), leading to information about specific elements of the text, such as the apple, the biblical episode of the Original Sin, and about the drink Campari, for instance. For the continuous format, all and the same information presented by the links at the hypertextual format was transformed into a continuous and articulated continuous text below the image of the ad (Appendix 2).

\section{Task}

The students were asked to read the text on the computer in order to answer some questions about it afterwards. Half of the students read the text in the hypertext format while the other half read it in the continuous format. They were asked to answer eight questions about the text after reading it. Except for the first question, they could always refer back to the text in order to read it again or check information. They read the text on the computer screen and typed their answers into specific pages in the computer.

The questions presented to the students after the text intended to test different reading abilities: global comprehension of the text, information retrieving, inference production, and giving opinion. This last ability, despite not being an ability strictly related to reading, was included as it could give us additional information about the students' comprehension of the text.

\section{Analysis}

The answers given by the students for each question were quantified according to their adequacy. Were considered adequate the answers in which the students accomplished the ability tested by the question (global comprehension of the text, information retrieving, inference production, and giving opinion). On 
the other hand, were considered inadequate, answers that were too vague or that did not show that the student reach the aim of the question. According to this quantitative analysis, the hypertext format generated slightly better results than the continuous format of the advertisement in all the reading abilities tested (Graphic 1). Although systematic, this difference could not be considered statistically significant, since the number of students that took part in this specific experiment is considered small ${ }^{3}$. Nevertheless, the results seem to point to the possibility that reading hypertext may be different from reading continuous texts ${ }^{4}$.

These results contradict one of our presuppositions, which speculated that the continuous format would generate better results in the questions that measure global comprehension, since in this version, unlike what was done in the hypertext version, the text was not fragmented. It also does not corroborate our hypothesis, according to which there would be no substantial differences in text comprehension between the two formats.

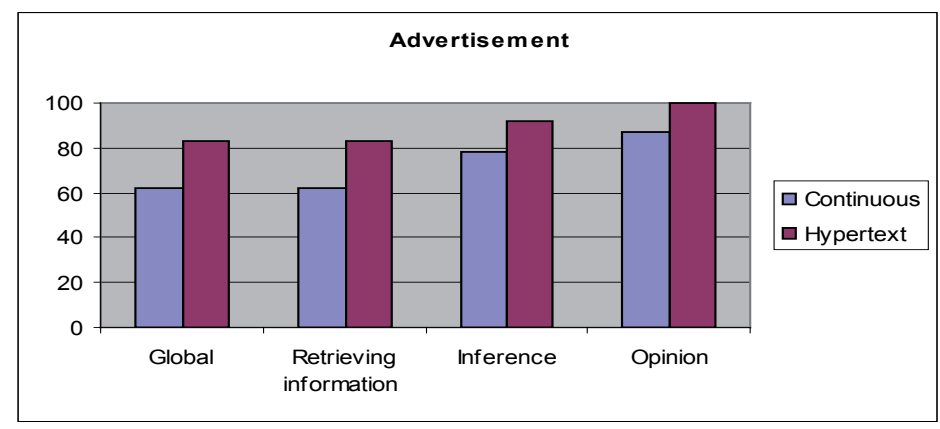

Graphic 1: Percentage of correct answers in each format, considering the reading ability focused

We believe that a quantitative analysis does not provide us with detailed information about the meaning construction made by the readers, and that we can not conclude unequivocally that there is significant difference between

3 This research is composed by four experiments alike the one described in this paper. As we considered relevant to make a qualitative analysis of the data, we chose to test a small number or students in order to make this kind of refined analysis possible.

4 The analysis of the data of the four experiments altogether, actually has shown that there is statistically significant difference only as far as the ability of retrieving information is concerned. 
reading in a hypertextual and in a continuous format without taking a deeper look at the data. Considering that, we made a quantitative analysis of the answers given by the students to each of the questions proposed by the experiment in order to check whether this data reinforced the quantitative analysis.

We present some parts of this analysis in the next sections.

\section{Global Comprehension}

The students' global comprehension was verified in two different questions in this text: one that asked the reader how he would explain the advertisement to a classmate, and another that asked him to identify the theme of the advertisement.

The aim of the first question - How would you explain this ad to a classmate? - was to verify the global comprehension of the text through a paraphrase. Students who read the text in the hypertext format performed well, showing us that they had noticed the connection among mental spaces that this text leads us to build.

This connection among mental spaces can be noticed in many answers that reveal the projections made by the readers in the mental spaces, and it also shows the interpretations that this integration makes emerge, as we can notice, for example, in the following answers:

Suj $15 \mathrm{H}^{5}$ : "Campari is an alcoholic drink and it is compared to the temptations of the Garden of Eden. It is red, like the fruit of $\sin$ (forbidden fruit) and the color of passion. Campari may be a drink that stimulates the most tempting feelings in a person."

Suj 19H: "It is an appealing ad that brings in a mix of symbols that manifest temptations, (referring to historic biblical contexts) through the drink. Campari would be the temptation itself, the prohibited and the arousal of sinful sensations."

The answers given by students that read the text in the continuous format also show that they have established the analogies indicated in the advertisement, as we can see in the following answers:

5 The data of each student received a code. The letter $\mathrm{H}$ in the end means that this student - Suj15 - read the hypertextual format. The letter is $C$ in the code means that the student read the continuous format. 
Suj. 13C: "I would say that it is composed by a "stylized" image of the bottle of Campari, with an apple in the composition, simulating the content of the drink. There is also a serpent next to the apple, as if it were attracted by the fruit that, in reality, is Campari. It is clearly an analogy to the sin of Adam and Eve and, besides these images, there are two sentences and the background is reddish, and seems to be a representation of Hell."

Suj. 31C: "The Campari ad (...) makes reference to sin and temptation, relating the biblical image of the apple with the drink. So, this comparison gives us the impression that Campari is so provocative that there is no way to avoid it."

The idea of comparison can be found in many of the answers given to this question, and is explicitly presented in the answers by means of expressions such as: "analogy" (Suj 13C), "compared to" (Suj 15H), "comparison" (Suj 23H), "referring to" (Suj $21 \mathrm{H}$, suj 19H), "in the same way as" (Suj 17H), "is related to" (Suj 30C), "makes and allusion to" (Suj 31C, Suj 44C), among others.

The answers that were not considered adequate do not make it clear if the analogies and connections among mental spaces were built by the students. As we can see in the following answers, one of the students simply described the advertisement (Suj45C), and the others did not present the existence of different mental spaces clearly enough nor the relationship among them. These students, however, mentioned the idea of "temptation" as a result of the connection among spaces.

Suj 45C: "The ad shows the image of a tree, with a serpent on one of the branches and a bottle next to it with the image of an apple inside, as if the apple was inside the bottle. At the bottom of the ad it is written "He provokes" and next to it "only he is like this", written in red. The bottle is a Campari."

Suj. 44C: "one apple and a serpent make an allusion to the power of temptation of this drink"

Suj. 46C: "In the ad, the apple, a symbol of temptation, represents Campari"

These answers were not considered satisfactory as an explanation of the advertisement, but do not necessarily show that the subjects did not build an adequate representation of it.

Other answers given to other questions show us that the readers were able to activate and integrate different mental spaces and, as a consequence, build adequate representations for the text. Suj44C, for example, did not mention the Bible, its characters and facts, in any of his answers, but some of the answers (questions 1, 2, 6 and 7) signal that he had made the connection between the apple and the drink, and inferred the consequences of this connection. 


\section{Suj 44C}

Question 2: What is the theme of the ad?

"The drink Campari and its power of seducing."

Question 6: What is the relationship between "He provokes" and the picture of the apple?

"The apple is inside the bottle. So, the drink has $\sin$ in itself, therefore it provokes."

Question 7: In the expression "Only he is like this", what does "like this" refer to? "To the power of temptation, to the apple that the drink contains."

This reader, in the answer to question 8, says that "this ad plays with highly stimulant symbols", making it clear that he had a much better global comprehension of the text than what was suggested by the answer to the first question.

Although Suj45C had only described the ad when answering the first question, answers to other questions, such as question 3, for instance, show that he had activated his knowledge about the biblical myth and had made the connections among the different mental spaces used in the advertisement.

\section{What does the images of the serpent and of the apples make reference to?}

Suj45C: "The images make reference to the biblical episode of Adam and Eve, who tried the apple offered by the serpent in Paradise. The reason why they tried the apple was that they were seduced by the idea of becoming gods."

It is interesting to note that this student presents one detail that was not mentioned by the other students and which does not seem to be part of the most common version of this myth - the fact that Adam and Eve "were seduced by the idea of becoming gods" - showing that many different elements can be activated during the comprehension of this text.

As far as Suj46C is concerned, although his answer was not considered adequate, since it is not a sufficient explanation of the advertisement, it can be noticed that he makes an association between apple, temptation and Campari. Establishing this relationship implies the activation and integration of mental spaces. Other answers given by this subject to other questions show more clearly the mental spaces that he activated and the connections he established among them, as for instance, in his answer to question 2: 


\section{Suj 46C}

Question 2: What is the theme of the ad?

"The comparison between the drink and the apple as symbol of temptation, making reference to the biblical text."

Global comprehension was also verified by the second question - What is the theme of the ad? In this question the results in the two formats are very similar (hypertext: $67 \%$, continuous: $63 \%$ of satisfactory answers). The students were expected to identify the theme, which is the original sin, as it can be seen in the following examples:

Suj13C: "The theme used in the ad is the scene of the original sin from the Bible" (...)

Suj17H: "The story of Adam and Eve, in which a serpent persuades Eve to eat the forbidden fruit - the apple - a symbol of sin."

Some answers were not considered adequate, since they do not show the theme clearly. Suj $15 \mathrm{H}$, for instance, explains the advertisement, but does not mention the theme - the original sin, and Suj23H mentions the product and the approach used in the ad but does not mention the theme.

Suj15H: "The ad stimulates people to have the same wishes and the same curiosity that Adam and Eve had when tempted by the serpent. But now it wants us to try the drink."

Suj23H: "The influence of the drink as a temptation to the man, which, from the human point of view, we can consider [the drink] as something "good" and tempting. A pleasure."

Despite not mentioning explicitly the theme, which was the aim of this question, these answers, as well as the answers given by most of the students, demonstrate their ability to activate and articulate different mental spaces. They show us the complexity of the mental activities that take place during text comprehension, and how the stimuli help emerge a wide network of concepts, beliefs and relationships among them, reinforcing the idea that we activate and integrate mental spaces when dealing with texts.

\section{Retrieving Information}

As far as finding explicit information on the text is concerned, the best results were found within the group that used the hypertext format (hypertext: $83 \%$, continuous: $63 \%$ of satisfactory answers). This result was predictable, since it is one of the qualities usually associated to hypertext (Rouet et al,1996; Landow, 1992). We believe that the quick access to information makes the work of 
finding information in the text easier and stimulates the reader to go back to the text more often than he usually does when reading continuous texts.

We are going to comment, however, on two answers considered inadequate:

Suj 15H: "the serpent shows us the temptations and curiosity involved in trying the drink. The apple shows us that the decision of whether we want to be protected and guided by God or not depends on our wish (in the case of obeying the rules) or if we want to make our own decisions in relation to our lives and want to try the mundane pleasures."

Suj 29C: "The serpent would be the consumer and the apple would be the drink."

We notice that these students, unlike those whose answers were considered adequate, elaborated different projections among the mental spaces. It was expected that the students recovered the information available in the text, which would establish the correlation between apple and sin and between serpent and temptation (Apple is sin, Serpent is temptation).

Suj12H presents the element which the serpent makes reference to - temptation - but does not present the element to which the apple would make reference. This answer shows us, however, the religious domain that he used to build his interpretation of the text.

Suj29C, on the other hand, establishes different connections among the mental spaces activated. Rather than relate the apple to sin and serpent to temptation, he activates a relationship of consuming, which is, in fact, what we may expect in the context of publicity. It is not an obvious relationship, however, since we usually expect the product to be the temptation and the consumer the "victim" of this temptation.

This reader seems to interpret the serpent as moving towards the apple in order to bite it. In this case, the serpent would be the element that is projected in the consumer. The serpent would not be the tempting one, but the element that is being tempted, and the apple would be, simultaneously, the tempter and the object of desire. This relationship is found in other answers given by this student, as in his answers to questions 6 and 8 , where he states that: "The image of the apple makes reference to the forbidden fruit that provoked Eve in Paradise. In the same way, He, Campari, provokes the desire of being consumed by people", and "he [the consumer] will feel like trying this irresistible drink." 


\section{Making Inferences}

In general, the students working in the hypertext format performed better at the inferential questions (92\%) than those in the continuous format (78\%). In both formats, however, it is possible to say that the performance of the students can be considered very good.

Students that read the text in the hypertext format got better results in three of the four cases of inferential questions (Graphic 2). This difference can point to the fact that, while reading in this format, the readers need to make more inferences, in order to connect the information presented in the links themselves and between the links and the main text.

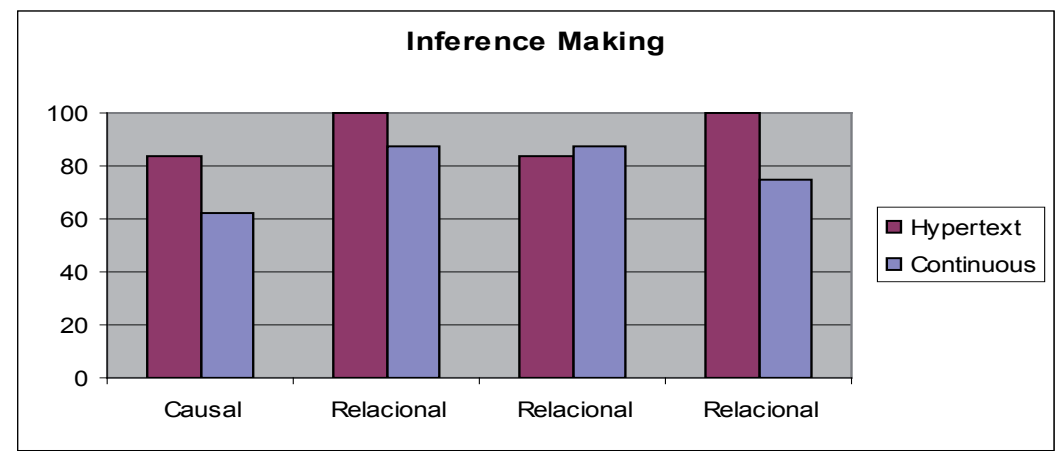

Graphic 2: Percentage of correct answers considering the ability of making different kinds of inference

Two kinds of inferences were verified in this experiment: causal inferences, in which the student had to deduce a cause-effect relationship between elements of the text, and relational inferences, which demand from the reader the ability to establish a relationship between two different elements of the text. In those questions the reader had to explain why the bottle is not shown in the picture, and build relationships between the word "he" and the other with different shapes, and between the expression "He provokes" and the image of the apple, besides identifying referents to the expression "only he is like this".

A very creative answer is given by Suj $15 \mathrm{H}$ to question 4 - Why only the label and the lid of the bottle are shown? This answer shows the construction of a complex causal relationship. 
Suj15H: "Because the drink is represented by the apple, that is to say, the drink is the forbidden fruit, temptation, an open door to the world of pleasures. And it is ready to be tried."

In this answer, the reader presents a complex relationship of identity between the apple, the drink and sin. He shows that the absence of the image of the bottle can be understood as a metaphor for the free access to pleasure, as a consequence of the easy access to the drink.

The high number of adequate responses to this question shows that the students could build connections among the elements in the text, revealing that they deal with compressions and decompressions during text comprehension. The answers given by Suj $17 \mathrm{H}$ and Suj47H are examples of that:

\footnotetext{
Suj17H: "To show the idea that the content of the bottle is the apple, which is red and provoking like the drink"

Suj47H: "This happens to show that the content of the hidden bottle is the forbidden fruit represented by the apple and the serpent."
}

These answers indicate how features of one element blend with features of another, indicating the construction of analogies among them, which enables them to share the same characteristics and the same "powers" or meanings. Campari becomes, therefore, a symbol of seduction as much as the apple, also evoking the complex network of relations and meanings that the apple ultimately compresses.

The answer given by Suj30C shows that this student used another frame to build an explanation for the absence of the bottle. According to him, the absence of the bottle does not matter, what matters is the presence of the label and of the lid, both of which remind us of the nudity of Adam and Eve.

\footnotetext{
Suj 30C: "Because when Adam and Eve were in Paradise, they only wore a tiny leaf to hide their sexual parts and in the case of Campari the label reminds us of this scene"
}

In spite of being plausible, this answer was not considered adequate, since this student does not seem to have established a relationship between the drink and the apple, and did not mention the idea of unity, identity or conceptual integration that the absence of the bottle suggests. We do not deny, however, that it is a plausible and creative answer that shows us the plurality of meanings our mental mechanisms allow us to build. 
In the answer to question 5 - The word "he" in the sentence "Only he is like this" is written in a different format. Why? - students needed to find a reason for the different font type used for the pronoun "he". It was expected that the students would notice that a candidate as reference to the pronoun "he" is the drink, and therefore, a different shape for this word is a way of emphasizing the product. As we can notice in the answers selected as examples, the students perceived this main purpose and went even further, presenting other reasons - as passion and sensuality - for the emphasis given to the pronoun, and bringing other interpretations for the color and font type used.

Suj 47H: This happens to emphasize the word "he", reinforcing the idea of a special product already in the sentence "only he is like this". Besides, there is an attempt to make reference to sensuality and provocation using that font.

Suj28C: "The word "he" is written in red in order to work as a symbol, since ancient times, of passion and sin. It is different in order to emphasize the meaning of uniqueness/singularity."

An interesting interpretation was given by $\mathrm{Suj} 19 \mathrm{H}$, for whom the use of the masculine pronoun "he" presents one element of the frame of seduction.

Suj19H: "Maybe the purpose of the use of this pronoun in the ad, besides making reference to the drink, is to induce a mix of meanings between Campari and someone masculine, both bringing a lot of sensuality."

Those answers show us how the verbal and non-verbal resources present in the text activate elements of the frames used in the mental spaces, and help emerge other elements and possible relationships within this context.

Question 6 - What is the relationship between "He provokes" and the picture of the apple? - requires that students notice that Campari, as well as the apple, is provoking objects of desire. Some answers demonstrate how the readers recover different contexts (and their frames) evoked by Campari and the apple, and how they establish the relationship among them.

Suj17H: "The expression "he provokes" is related to the apple showing that, just like the apple led Eve to sin, Campari also will cause people not to give in to temptation"

Suj46C: "As the serpent provoked Eve to eat the apple, so the drink provokes the consumer"

Different paths were used by other students, as the following:

Suj44C: "The apple is inside the bottle. So, the drink has $\sin$ in itself; therefore, it provokes." 
In this case, the reader presents the relation of identity between the apple and Campari. The apple is a symbol of sin and the drink contains the apple, therefore, the drink is as provocative as the apple.

Suj21H: "The relationship between the expression "he provokes" and the apple is that the apple is the object of temptation that will provoke on the consumer the desire of trying the drink that is being offered"

In this case, the apple provokes. This fruit would be the agent of the provocation, and not the desired object. This student establishes the apple as the element that provokes (instead of the serpent). The drink (or the apple) provokes by itself, and does not need another agent to do this, reflecting the conceptual integration that this advertisement suggests to the reader.

Similar cases were found in other answers, as in the answer of Suj45C, and seem to indicate other possibilities of construction and integration of the mental spaces involved in the comprehension of this text.

Suj45C: "The apple is related to desire and sin. It evokes the temptation of trying the forbidden fruit - the apple - which is equivalent to Campari. It can also be that the apple is in an "inferior" level in relation to Campari, since the apple needs the serpent to offer her (the apple), but Campari is by itself provocative."

This answer presents more details about the rational that justifies the answer given by Suj $21 \mathrm{H}$, explaining that Campari does not need to be offered because it is itself provocative. For this student the apple plays two roles: it is at the same time the agent of the temptation and the desired object.

This interpretation apparently contrasts with another one, in which Campari is the serpent and, therefore, is the agent of temptation, as we can see in the next answer:

Suj13C: "Campari stimulates, provokes (someone) to try the "forbidden fruit", it would take the role of the serpent."

In this case, Campari is the agent of temptation, and the seduced one (the 'victim') would be someone who would try the "forbidden fruit" that seems to be a new element, the sexual act. This becomes more evident in the answers this reader gives to questions 7 and 8 , in which he mentions the "aphrodisiac power of the drink".

It is worth noticing that in his answer to the first question, this reader (Suj13C) says that, in the advertisement, the serpent is being attracted by 
the apple, indicating that the serpent does not play the role of the agent of seduction, but the role of the one being seduced ("there is also a serpent next to the apple, as if she has been attracted by the fruit"). He makes an inversion of the expected roles. In fact, in the image, the serpent seems to be going towards the apple, so, getting into the conclusion that the serpent will eat the apple is a plausible inference (although it does not take the biblical myth into consideration).

In spite of showing slightly different interpretations of the advertisement, there seems to be a common aspect among those answers (Suj21H, Suj29C, Suj13C and probably in Suj45C). We can't find three elements in the answers, that is, there are not the figures of the agent of the temptation, the seduced one ("victim") and the object of desire. There are only two: the tempter and the tempted. Those answers show how students integrated the mental spaces activated. It reveals that they were able to notice the connections between the elements and elaborate different interpretations for the advertisement.

The last inferential question is also relational. In the answer to the question - In the expression "Only he is like this", what does "like this" refer to? - readers were expected to present the meaning that they built to one expression used in the text.

Most answers show that students interpreted "like this" as "tempter", "seductor", "provocative". Two answers did not follow this pattern:

Suj28C: "like this" refers to Campari. Because it is good.

Suj30C: It refers to the fact that it is red as the apple.

Suj28C takes Campari as the referent of "like this". Actually, the word that recovers Campari in the advertisement is the pronoun "he" rather than the expression "like this". Suj30C, only mentions the similarity of colors in the apple and the drink, without mentioning explicitly any other meaning to the word highlighted in the question. It is not clear what exactly these two students had in mind.

\section{Giving opinion}

The last question of the experiment required an opinion about the efficiency of the advertisement. The best results verified among those who used the hypertext format, when compared to the continuous was not expected, since there is no reason for the influence of the text presentation format on the students' 
ability to express a personal opinion. This difference was caused by the answer of a student who, actually, did not give an answer that could be considered inadequate, but was not considered satisfactory, as he only answered vaguely the first part of the question. This difference is not significant, and will tend to disappear when testing a larger number of students.

Suj30C: For sure. It is very attractive.

The answers given by the students to this question emphasize even more the correlations that they make among elements in the different domains involved in this ad, and the different times and spaces that need to be integrated in the comprehension of this text. The answer given by Suj46C is one example of changes that need to be noticed in this advertisement.

Suj46C: "In the ad Campari is unique, it is the unique temptation. It substitutes the apple today and the target public would be those people who "look for temptations", who go out, drink, and so on."

Suj28C: "The reader is stimulated by curiosity. The serpent, the apple, and the "pieces" of the bottle show that the drink is much more than the word means. It is temptation in itself. From the moment someone tries it, he or she will never stop drinking".

In those answers, the students understand Campari as blending different elements of the text, which makes it unique for compressing different features of those elements. The answer given by Suj46C shows also that this student, like many others, notices a change of values in time and space: at Adam and Eve's time, the desired object was the apple, nowadays it is Campari; at that time people feared sin, now people search for it.

Other answers also reinforce this idea of rupture with the past, or the changes that took place during long history of mankind. The ad seems to work as a permission to sin, a good reason to fall into temptation. The drink would be a way of getting rid of the pressures and restrictions imposed to the human being by society and religion.

Suj21H: "This ad is efficient, and stimulates the consumers to drink the product, because it denies strong elements of the Bible, that is, even very religious people will be able to drink, because if even Adam and Eve committed sins, why can't common people do it?"

Suj17H: "Besides being creative, this ad convinces the reader that he should have the product in order to be free from the social and religious constraints, and makes him feel free to fall into temptations and sin." 
Suj47H: "This ad works, because it attracts the reader and stimulates him to buy the drink, even if the drink can harm his health. The metaphor of the forbidden fruit is a good and well elaborated argument. The ad justifies the consumption of the drink"

The answers show how the ad stimulates the reader's curiosity and imagination, by using symbology and choosing a controversial theme. They also point to these characteristics as the main reason for the efficiency of this text. The activation and integration of different mental spaces is seen by the students as provocative and stimulating.

Suj19H: "Persuasion is guaranteed. The biggest temptations of mankind are certainly in carnal pleasures, and this is exactly the symbology used in the ad. Desire is attached to consuming."

Suj 44C: "Besides being aesthetically beautiful, this ad plays with highly stimulating symbols, achieving its aim to motivate the reader to drink the product."

\section{Final considerations}

In order to verify the influence of the presentation format of the text in reading comprehension, we made an experiment in which students who are familiar with computers read an advertisement in one format: hypertext or continuous. After reading the text the students answered questions that aimed to verify some reading skills: global comprehension, retrieving information, making inferences and giving opinion.

According to quantitative analyses of the answers, students that read the text in hypertext format achieved better results in all skills. This seems to show us that hypertexts help readers to deal with texts in a more effective way in comparison to the continuous format. It seems that hypertext offers a friendlier interface, and a better usability than the continuous format, stimulating students to go back to the text whenever it is necessary in order to find explicit information, to check their comprehension as well as to ratify their answers. Besides that, as the texts presented in each link is short, hypertext may help students to focus their attention to the text, and makes it easier for them to grasp the main idea of each part of the text, helping them to build the central idea of the whole hypertext more easily.

This does not mean, however, that the continuous format makes text comprehension harder. A qualitative analysis of the answers demonstrates that the students, regardless of the presentation format, could understand well the advertisement, and were able to deal with different mental spaces in a very 
creative and efficient way. This means that we have to keep on making research on this area in order to know more precisely in with aspects hypertexts are more effective than the continuous format.

This experiment raises many questions, among which whether the same results will be found in other kinds of texts such as, for instance, texts that are mainly verbal rather than visual, or whether the results will vary depending on the familiarity of the student with the subject. We can also ask if we would have the same results when testing students whose level of reading proficiency is lower.

This experiment is part of a set of similar experiments, in which other kinds of texts have been tested. We hope that a global analysis of the experiments brings answers to those questions and gives us a better understanding

\section{References}

Coscarelu, Carla Viana. Da leitura de hipertexto: um diálogo com Rouet et al. In: Araújo, Júlio César, Biasi-Rodrigues, Bernadete (Orgs.). Interação na Internet: Novas formas de usar a linguagem. Rio de Janeiro: Lucerna, 2005. p 109-123.

Coscarelu, Carla Viana. Entrevista: Uma conversa com Gilles Fauconnier. Revista Brasileira de Lingüistica Aplicada, v.5. n.2. 2005. p. 291-303.

Coscarelu, Carla Viana. Os dons do hipertexto. Littera: Revista de Lingüistica e Literatura. Pedro Leopoldo: Faculdades Integradas Pedro Leopoldo, v.4, n.4, jul/dez, 2006. p.7-19.

Fauconnier, Gilles, SweetSer, Eve. Spaces, Worlds, and Grammar. Chicago: The University Chicago Press, 1996.

Fauconnier, Gilles, Turner, Mark. The Way We Think: Conceptual Blending and The Mind's Hidden Complexities, Cambridge University Press, 2002.

FAUCONNIER, Gilles. Mappings in Thought and Language. Cambridge: Cambridge University Press, 1997.

FAUCONNIER, Gilles. Mental Spaces: Aspects of Meaning Construction in Natural Language. Cambridge: Cambridge University Press, 1994.

Landow, George P. Hypertext 2.0. Baltimore: Parallax, 1992.

RamaL, Andrea Cecília. Educação na cibercultura. Porto Alegre: Artes Médicas, 2002.

Rouet, Jean-Franç̧ois, Levonen, Jarmo, DiLlon, Andrew, SPIRo, Rand. Hypertex and cognition. USA: Lawrence Erlbaum Associates, 1996.

SNYDER, llana. Hypertext. The electronic labyrinth. Melbourne: Melbourne University Press, 1996.

Xavier, Antônio Carlos. Leitura, texto e hipertexto. In.: Marcuschi, Luiz A., Xavier, Antonio C. (orgs.) Hipertexto e gêneros digitais. Rio de Janeiro: Lucerna, 2004. p.170-180. 


\section{Appendix 1}

\section{Hypertextual format}

Here are some frames of the navigation in the hypertextual version of the text. The complete version includes all and the same information presented in the continuous format.

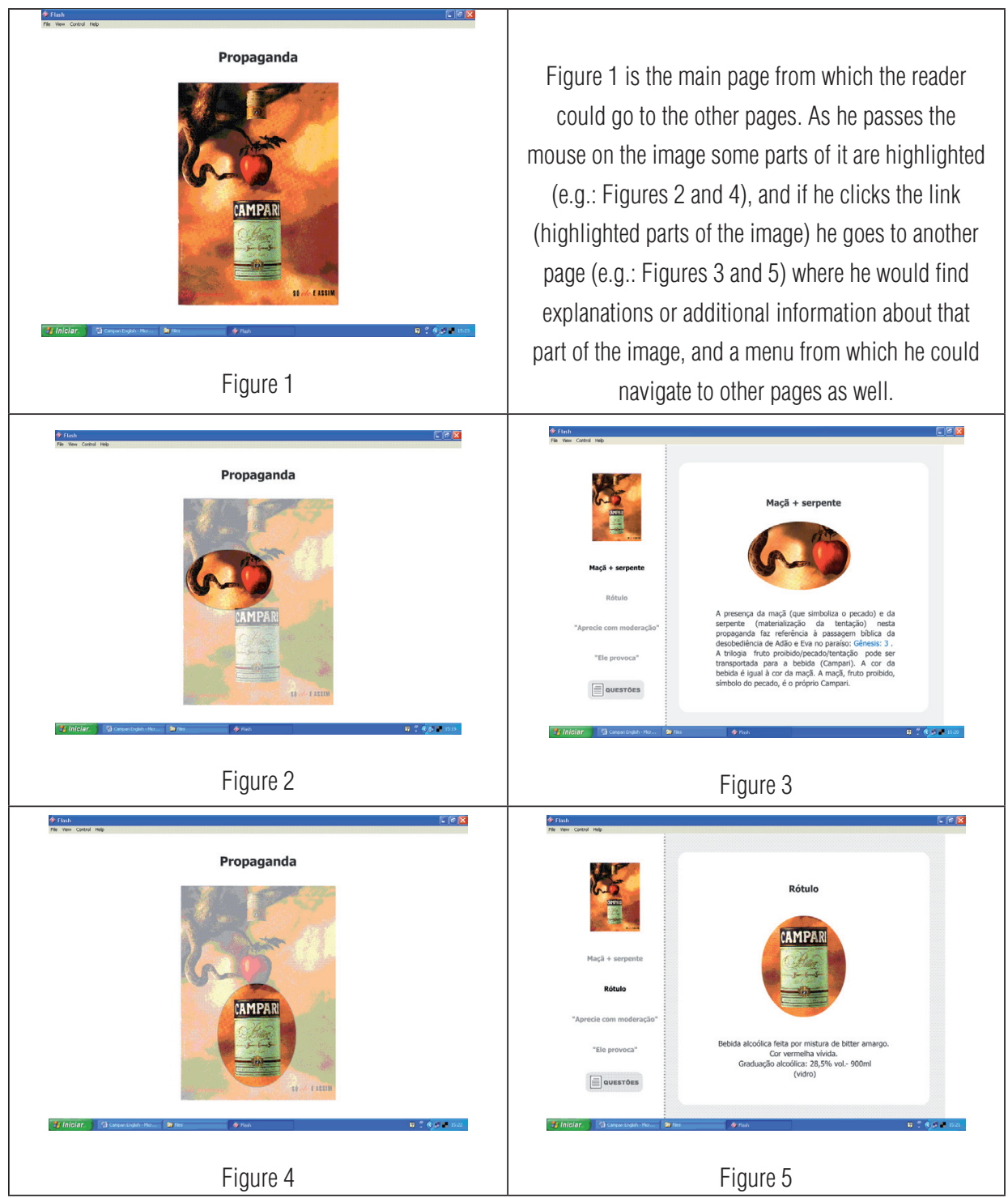




\section{Appendix 2: Continuous format}

A propaganda de Campari, assim como todo texto pertencente ao gênero propaganda, tem como objetivo promover e divulgar um produto. Campari é uma bebida alcoólica feita por mistura de bitter amargo na cor vermelha vívida, com graduação alcoólica de $28,5 \%$ vol. $900 \mathrm{ml}$. Normalmente, uma propaganda bem sucedida seria aquela que faz com que o seu leitor/consumidor adquira o produto divulgado.

Vejamos quais estratégias são usadas na propaganda acima:

A presença da maçã (que simboliza o pecado) e da serpente (materialização da tentação) faz referência à passagem bíblica

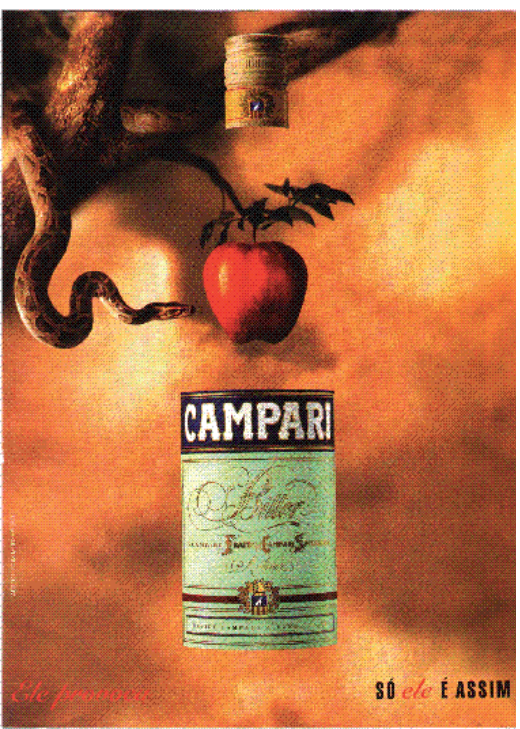
da desobediência de Adão e Eva (pecado original) no paraíso: Gênesis: 3. 1-6.

Eis o texto de Gênesis: "Ora, a serpente era mais astuta que todas as alimárias do campo que o Senhor Deus tinha feito. E esta disse à mulher: É assim que Deus disse: Não comereis de toda a árvore do jardim? E disse a mulher à serpente: Do fruto das árvores do jardim comeremos, Mas do fruto da árvore que está no meio do jardim, disse Deus: Não comereis dele, nem nele tocareis para que não morrais. Então a serpente disse à mulher: Certamente não morrereis. Porque Deus sabe que no dia em que dele comerdes se abrirão os vossos olhos, e sereis como Deus, sabendo o bem e o mal. E viu a mulher que aquela árvore era boa para se comer, e agradável aos olhos, e árvore desejável para dar entendimento; tomou do seu fruto, e comeu, e deu também a seu marido, e ele comeu com ela."

A trilogia fruto proibido/pecado/tentação pode ser transportada para a bebida (Campari). A cor da bebida é igual à cor da maçã. A maçã, fruto proibido, símbolo do pecado, é o próprio Campari.

Na Expressão "Só ele provoca", mais uma vez, temos uma apologia ao pecado, à tentação (representada pela figura da serpente e da maçã). O uso da 
cor vermelha nas letras também nos remete à maçã, ao Campari e ao próprio significado que a cor vermelha já carrega consigo, nos remetendo à tentação e à paixão. Só o Campari provoca porque ele é a própria tentação.

Por se tratar de uma propaganda de bebida alcoólica, a expressão "Aprecie com moderação”, que aparece no lado esquerdo da página, é obrigatória, pois todo anúncio desse tipo de produto, qualquer que seja o meio empregado para sua veiculação, conterá "cláusula de advertência" a ser adotada em resolução específica do Conselho Superior do CONAR, a qual refletirá a responsabilidade social da publicidade e a consideração de anunciantes, agências de publicidade e veículos de comunicação para com o público em geral. Diante de tais compromissos e da necessidade de conferir-lhes plena eficácia, a resolução levará em conta as peculiaridades de cada meio de comunicação e indicará, quanto a cada um deles, dizeres, formato, tempo e espaço de veiculação da cláusula. Integrada ao anúncio, a "cláusula de advertência" não invadirá o conteúdo editorial do veículo; será ostensiva e enunciada de forma legível e destacada.

\section{THE AUTHOR}

Carla Viana Coscarelli Holds a postdoctoral degree in Cognitive Science from University of San Diego, California (2005) and a PhD in Linguistics from Universidade Federal de Minas Gerais (1999). She has been a teacher at Faculdade de Letras at Universidade Federal de Minas Gerais since 1995. Lately she has developed research on reading, mainly, how people read hypertexts; and digital literacy, trying to figure out efficient ways to use new technologies in order to contribute to alphabetization and literacy of young children. E-mail: cvcosc@yahoo.com.br 